\title{
Bacteriological Analysis and Public Health Impact of Broiler Meat: A Study on Nalitabari Paurosova, Sherpur, Bangladesh
}

\author{
Md. Omar Faruque1, Shahin Mahmud1, Md. Abul Munayem¹, Razia Sultana², Md. Tarek Molla1, \\ Md. Firoz Ali', Muhammad Wasim¹, Sourav Sarker1, Fatematuz Zuhura Evamoni2 ${ }^{*}$
}

${ }^{1}$ Department of Biotechnology and Genetic Engineering, Mawlana Bhashani Science and Technology University, Santosh, Tangail, Bangladesh

${ }^{2}$ Department of Biotechnology and Genetic Engineering, Noakhali Science and Technology University, Sonapur, Noakhali, Bangladesh

Email: *eva.nstu@yahoo.com

How to cite this paper: Faruque, M.O., Mahmud, S., Munayem, M.A., Sultana, R., Molla, M.T., Ali, M.F., Wasim, M., Sarker, S. and Evamoni, F.Z. (2019) Bacteriological Analysis and Public Health Impact of Broiler Meat: A Study on Nalitabari Paurosova, Sherpur, Bangladesh. Advances in Microbiology, 9, 581-601. https://doi.org/10.4236/aim.2019.97036

Received: April 16, 2019

Accepted: July 19, 2019

Published: July 22, 2019

Copyright () 2019 by author(s) and Scientific Research Publishing Inc. This work is licensed under the Creative Commons Attribution International License (CC BY 4.0).

http://creativecommons.org/licenses/by/4.0/

(c) (i) Open Access

\begin{abstract}
Broiler meat is one of the most important protein sources for Bangladeshi people. Food-borne diseases associated with the consumption of poultry meat and its processed products are of public health concern worldwide. An investigation was conducted to assess the bacteriological quality of poultry meat from some poultry farms and its health impact on consumer of Nalitabari paurosova, Sherpur district, Bangladesh. Total 15 samples were randomly selected and collected from different poultry farms on the basis of farms level and size. Bacteriological quality of the samples was assessed by following the standard microbiological methods. The health impact was evaluated with the help of semi-structured based questionnaire of 400 peoples. The average value of TVC and TCC were found as $4.3 \times 10^{6} \mathrm{CFU} / \mathrm{g}$ and $3.6 \times 10^{4} \mathrm{CFU} / \mathrm{g}$ respectively. In this study, the prevalence of fecal coliform was recorded as $33 \%$ and the presence of $E$. coli in $53 \%$ samples. The mean value of Salmonella spp. of meat samples was $4.6 \times 10^{3} \mathrm{CFU} / \mathrm{g}$. No Shigella spp., Vibrio spp. and fungal species were detected in any sample. Some selected isolates were tested for their sensitivity against some commercially available common antibiotics used in Bangladesh. E. coli was $80 \%$ resistance to Ampicillin and $90 \%$ sensitive to Ciprofloxacin whereas Salmonella spp. showed $100 \%$ resistance to Ampicillin and $80 \%$ sensitivity to Ciprofloxacin. The antibacterial activity of renowned medicinal plant Azadirachta indica was also evaluated against some multidrug resistance bacteria. The inhibitory zone of both $30 \%$ methanolic and ethanolic extracts of Azadirachta indica was $12 \mathrm{~mm}$ and $12.3 \mathrm{~mm}$, where $40 \%$ methanolic and ethanolic extracts were $14 \mathrm{~mm}$ and $16.3 \mathrm{~mm}$ against
\end{abstract}


E. coli. The $40 \%$ ethanolic extract showed the better activity between them. The plant extract has no activity against Salmonella spp.. Awareness and health impact of broiler meat was determined among the people of different sectors on the basis of educational qualification, socio-economic condition, income source, broiler meat intake pattern, BMI range and food related diseases they have suffered. The peoples who eat broiler meat are much more prone to complicated diseases than the peoples who never eat it. So broiler meat intake pattern must be changed for better health. The widespread occurrence of Salmonella spp. and E. coli in poultry meat also reinforces the need for effective control measures.

\section{Keywords}

Broiler Meat, Total Viable Count (TVC), Total Coliform Count (TCC), Antibiotic, Azadirachta indica, Public Health, Nalitabari

\section{Introduction}

Broiler meat production has been growing faster since the 1960s and it becomes the fastest growing sector in meat production through worldwide [1]. In Bangladesh, broiler meat is popular in the consumer market because of its easy digestibility and as a low-cost source of animal protein. The modern poultry industry can provide prepared broiler chickens in less than six weeks through genetic selection, improved feeding and keen health management practices. Nowadays antibiotics are used as therapeutic agents to treat bacterial diseases in intensive farming systems [2] [3] because poultry meat offers an excellent medium for the multiplication of many bacteria even which are not inhibited by low temperatures. Storage of processed poultry meat is essential and considered only under circumstances which inhibit the multiplication of the initial load of bacteria [4]. Special attention should maintain because live animals are hosts to a large number of different microorganisms residing on their skin or feathers. During slaughter most of these microorganisms are eliminated. Contamination is possible at any stage of the production process, from feather plucking to freezing. Microorganisms from the environment, equipment and operators hands can contaminate the meat too [5] [6].

Poultry meat has significant contribution to the human diet [7]. The modernization of chicken farms and globalization of the bird breeding trade have played a role in infection [8]. During the slaughter of poultry birds there can be fecal contamination of the carcasses from the gut of these birds which means bacteria present in the spilled gut contents is passed on as contaminants [9]. Although due to short production time and low investment small scale commercial boiler farms are gradually rising but contamination of poultry meat with food borne pathogens remains an important health hazardous issue [10]. Foodborne diseases are great public health concerns of the modern world. Especially developing countries are largely affected by foodborne infections. These diseases af- 
fect people's health and have an economic impact on the countries [11]. Bangladesh, as a developing country, have concerned about the foodborne diseases and economic impacts, because poultry industry is one of her significant source of income [12]. There are many regulatory agencies responsible for ensuring food safety and quality assurance. They are offered to the consumers that poultry chicken will be pure and healthful. Such agencies belonging to International forum include the Food and Agriculture Organization (FAO), World Health Organization (WHO), United Nations International Children's Emergency Fund (UNICEF) and CAC [13].

The significance of different foodborne diseases varies among countries depending on foods consumed, food processing, preparation, handling, storage techniques employed and sensitivity of the population. Microbiological food borne diseases are usually caused by bacteria or their metabolites, parasites, viruses or toxins [14]. The bacteria E. coli and Salmonella infections of poultry have been shown to be of critical importance in Bangladesh. Meat can be contaminated with E. coli during slaughter of the animals. E. coli from meat has mostly been associated with intestinal pathogenic E. coli. But many studies also proved that $E$. coli of animal origin has been shown to be associated with extra-intestinal infections, such as urinary tract infections [15]. Among the diseases caused by $E$. coli spp. some are often severe and sometimes causes lethal infections such as meningitis, endocarditis, septicemia, epidemic diarrhea of adults and children [16]. The health hazard from Salmonella spp. must be estimated because they have shown the enumeration of microbial indicators of fecal contamination. Salmonella was also detected in frozen samples from the supermarkets which indicates that the spread of infection is confined to apparently unhygienic environments [17] and the animal itself may be initially contaminated [18]. Most Salmonella found on poultry meat are non-host-specific. They are considered to capable of causing human food poisoning. Salmonellosis is the most common disease in human caused by Salmonella spp. [19].Worldwide epidemiological reports incriminate poultry meat as a source of outbreaks of human foodborne disease. These outbreaks are caused by undercooking meat, cross-contamination of ready products to eat with microbial contaminants from the raw poultry. Poultry industry take aim to find ways to avoid contamination of live poultry and poultry products with potential pathogens [20]. Microbiological quality of processed carcasses mostly depends on a healthy condition and external micro flora of an animal [21] and the hygienic conditions during slaughtering and processing [22] [23]. Foodborne diseases are not only associated with the consumption of poultry meat but also its processed products which have a great public health significance [24]. The relationship between the consumption of meat and health is multifaceted. The relevance of poultry meat for humans has been recognized by the United Nations (UN) Food and Agricultural Organization (FAO). These organizations have considered poultry meat as widely available, relatively inexpensive food to be particularly useful in developing countries, where it also can help to meet shortfalls in essential nutrients [25]. 
Microorganisms have developed resistance against many antibiotics [26] and antibiotics are sometimes associated with side effects too [27]. Though there are some advantages of using antimicrobial compounds of medicinal plants [28]. In particular, Azadirachta indica (local name-neem) is one of the most promising medicinal plants which have several biological activities such as antioxidant, anti-inflammatory, antibacterial, antifungal, and antiulcer ones [29] [30] [31] [32]. These biological activities are attributed to the presence of many bioactive compounds in its different parts. For example aqueous extract of Neem leaf extract has a good therapeutic potential as an antihyperglycaemic agent in insulin-dependent and non-insulin-dependent diabetes mellitus [33]. The phytochemicals like alkaloids, glycosides, flavanoids and saponins which are importance components of Azadirachta indica contain antibiotic principles of plants. They help in the defensive mechanism of the plants against different pathogen [34]. It is now considered as a precious source of unique natural products for development of medicines against various diseases [35]. The main objectives of our study was to investigate the microbial load of broiler meat, its impact on public health, antibiotic resistance pattern of these isolated bacteria and to seek a fruitful way for successful application of medicinal plants to minimize the hazards and risk related to bacterial contamination in poultry farms.

\section{Method and Materials}

\subsection{Study Area}

The study was conducted at different area of Nalitabari paurosova (Figure 1) in

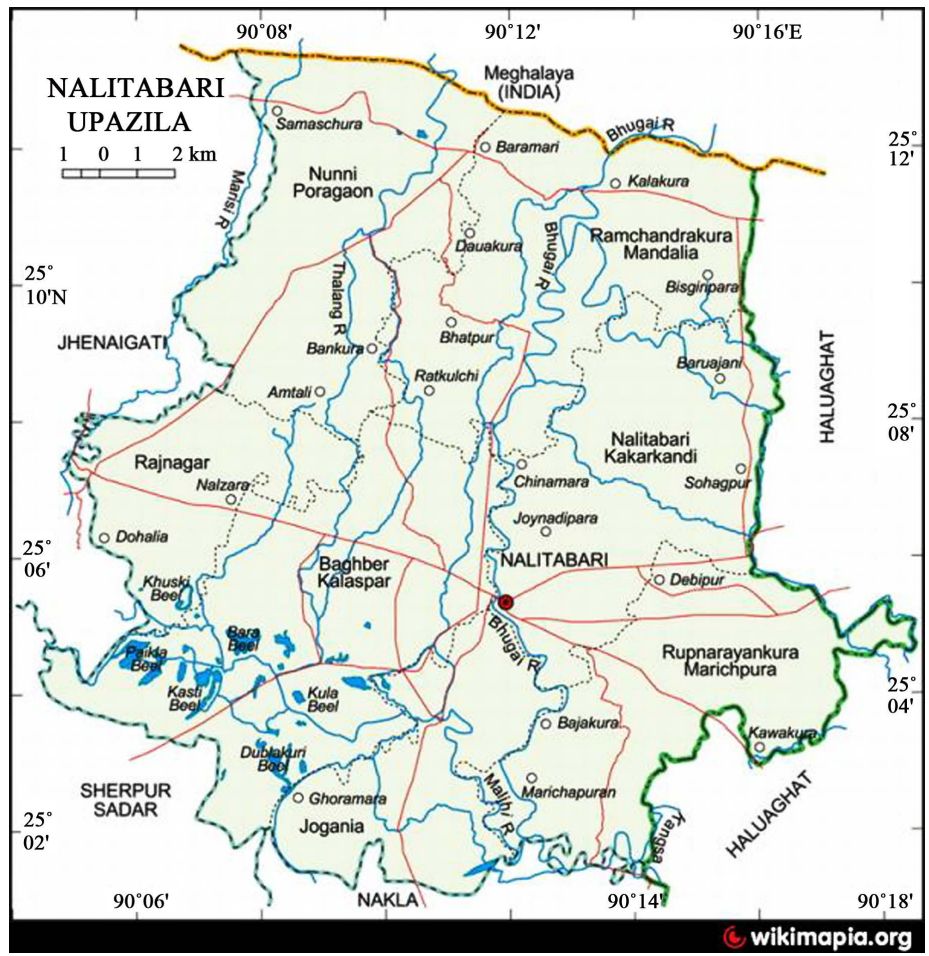

Figure 1. Geographical location of the study area. 
Sherpur district of Bangladesh during the periods of February 2015 to December 2018. Recently, huge number of poultry firm were established in this area that was an important reason for analyzing the poultry meat and all the samples were collected from poultry farms located in this region.

\subsection{Collection of Samples}

Fifteen samples were aseptically collected from study area. The slaughtered broilers at first immersed in a special tank containing hot water for some time. The immersed birds were de-feathered traditionally by hand plucking and subsequently evisceration was done using special tricks or techniques. The muscle of breast region were cut and put into a sterilized container. During transportation the sterile containers were kept cool in iceboxes containing fragments of ice.

\subsection{Anthropometric Assessment}

The anthropometric data were collected based on literature review of similar existing study [36]. In this study, randomly 400 respondents were selected by semi structured questionnaire based cross-sectional population selection system from study area. Among total respondents, 200 were females and 200 males. Age of the subjects under this study was determined by interrogation and confirmed with birth certificate or the health card. Measurements of weight were obtained by digital machine at three times and the average was calculated with minimal clothes and bare footed. The height was measured using a measuring tape without shoes and the average was calculated and recorded with standard error. Body Mass Index (BMI) was computed using the following standard equation: BMI = Weight $(\mathrm{kg}) /$ height $\left(\mathrm{m}^{2}\right)$ [37]. Based on the interrelationships of height, weight, age, height for age, weight for age and height for weight have been calculated to determine their nutritional status [38]. Nutritional status (such as: thinness, malnourished, obesity, normal weight and overweight etc.) was evaluated following the recently published international BMI cut off points [39].

\subsection{Preparation of Sample for Bacteriological Studies}

Each of the raw meat samples was macerated in a mechanical blender using a sterile diluent as per recommendation of International Organization for Standardization (ISO). Ten grams of the breast meat sample was taken aseptically with a sterile forceps and transferred into sterile containers containing $90 \mathrm{ml}$ of $0.1 \%$ peptone water. A homogenized suspension was made in a sterile blender. Thus 1:10 dilution of the samples was obtained. Later on, different serial dilutions ranging from $10^{-2}$ to $10^{-9}$ were prepared according to the standard method [40].

\subsection{Enumeration of TVC and TCC}

For the determination of TVC and TCC, $100 \mu \mathrm{l}$ of each ten-fold dilution were transferred and spread on Plate Count Agar (PCA) and MacConkey agar using a 
fresh pipette for each dilution. The diluted samples were spread as quickly as possible on the surface of the plate with a sterile glass spreader. The plates were then kept in an incubator at $37^{\circ} \mathrm{C}$ for 18 hours. The average number of colonies in a particular dilution was multiplied by the dilution factor to obtain the total viable count. The TVC and TCC were calculated according to ISO [40]. The results of the total bacterial count were expressed as the number of organism or colony forming units per gram (CFU/gm) of meat sample [41].

\subsection{Enumeration of Pathogenic Bacteria}

For the identification of pathogenic bacteria, $100 \mu \mathrm{l}$ of each sample were transferred into Thiosulfate Citrate Bile Salts Sucrose Agar (TCBS) media and Shigella Salmonella Agar (SS) media with ten-fold dilution. The diluted samples were spread as quickly on the surface of the plate with a sterile glass spreader and incubated at $37^{\circ} \mathrm{C}$ for overnight. The presence of pathogenic bacteria were observed and counted.

\subsection{Statistical Analysis of Experimental Data}

The data on TVC and TCC obtained from the bacteriological examination of meat samples of the poultry carcass collected from different area of Nalitabari. Data were analyzed with Microsoft Office Excel-2013 [41].

\subsection{Cultural and Biochemical Examination of Samples}

The cultural examination of chicken breast meat samples for bacteriological analysis was done according to the standard method by International Commission on Microbiological Specifications for Foods (ICMSF) [42]. The examination followed detail study of colony characteristics including the morphological and biochemical properties. In order to find out different types of microorganisms in chicken breast meat samples, different kinds of bacterial colonies were isolated in pure culture from the Plate Count Agar (PCA), MacConkey agar, SS agar and TCBS agar and subsequently identified according to the methods described by Krieg et al. [43]. Gram staining and biochemical reaction were performed for further confirmation of presumptively identified bacteria according to Bergey's Manual Determinative Bacteriology [44]. Among these 15 samples 12 kinds of biochemical test such as Kligler Iron Agar (KIA), Motility-Indole-Urease (MIU), Citrate, Voges Proskauer (VP), Oxidase, Catalase, Mannitol, Starch, Methyl Red (MR), Glucose, Lactose, Eosin Methylene Blue (EMB) were performed.

\subsection{Antibiotic Susceptibility Testing}

The antibiotic susceptibility of the Escherichia coli and Salmonella spp. isolates was determined according to the standard disc-diffusion method [45]. Well isolated single colony obtained from overnight grown cultures, were used for making young culture for the test. The commercially available antibiotic discs (Oxo-

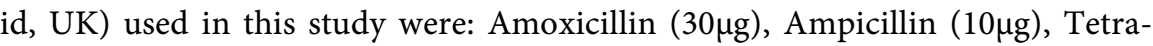


cycline $(30 \mu \mathrm{g})$, Nalidixic Acid $(30 \mu \mathrm{g})$, Ciprofloxacin $(5 \mu \mathrm{g})$, Norfloxacin $(10 \mu \mathrm{g})$, Erythromycin $(15 \mu \mathrm{g})$ and Gentamicin $(10 \mu \mathrm{g})$.

\subsection{Preparation of Plant Extracts}

Healthy and disease free plant leaves of Azadirachta indica were collected from nearby area. The freshly collected leaves were washed with tap water, $70 \%$ ethanol and then distilled water to sterilize and remove the external impurities. These were further slice into small pieces and shade dried for two weeks and then blended into powder using mortar. The powdered leaves of $A$. indica were separately extracted with different solvents (30\%, 40\% of ethanol and methanol) by using Whatman No. 1 filter paper. The crude extracts were obtained by concentrating the mixture solution using a rotary evaporator and used for further tests.

\section{Antibacterial Screening Test for Plant Extract}

Young culture of bacterial aliquots of the test organisms in $4 \mathrm{ml}$ sterile Mueller Hinton Broth (MHB) were made from well isolated single colony obtained from $24 \mathrm{~h}$ growth cultures. Each aliquots $(10 \mu \mathrm{l})$ containing approximately $5 \times 10^{4}$ bacterial cells or colony forming units was transferred into Mueller-Hinton Agar (MHA) plates. The disc containing plant extract were diffused into the plate where, the extract allowed to stands for an hour for reaction to take place between the extracts and the bacterial organisms. The plate were then inoculated on separate and incubated at $37^{\circ} \mathrm{C}$ for 18 hours.

\section{Results and Discussion}

\subsection{Microbiological Analysis}

\subsubsection{Total Viable Count (TVC)}

International Commission on Microbiological Specifications for Foods (ICMSF) recommended that the general viable count of fresh meat tissue at $35^{\circ} \mathrm{C}$ should be less than $10^{6} \mathrm{CFU}$ per gram [42]. The average value of total viable count (TVC) of 15 samples was $4.3 \times 10^{6} \mathrm{CFU} / \mathrm{gm}$. The lowest TVC was found $2.3 \times$ $10^{4} \mathrm{CFU} / \mathrm{gm}$ (sample 3) and highest was $3.6 \times 10^{7} \mathrm{CFU} / \mathrm{gm}$ (sample 13). Other studies reported the range of TVC from $6.1 \times 10^{6}$ to $6.5 \times 10^{5} \mathrm{CFU} / \mathrm{gm}$ [46]. Another study revealed that the mean value of total viable count of chicken meat was $5.0 \times 10^{5} \mathrm{CFU} / \mathrm{gm}$ [47] and $1.3 \times 10^{6} \mathrm{CFU} / \mathrm{gm}$ [48].

\subsubsection{Total Coliform Count (TCC)}

Total coliform count is the key indicator of the severity of bacterial contamination of broiler meat and its suitability to human consumption. In most cases of processed broiler meat, the high quantity of coliform bacteria causes severe food poisoning especially among children. In this study, the lowest value of TCC was found $1.6 \times 10^{3} \mathrm{CFU} / \mathrm{gm}$ (Sample 3) and the highest was $1.5 \times 10^{5} \mathrm{CFU} / \mathrm{gm}$ (Sample 8). The mean value was obtained as $3.6 \times 10^{4} \mathrm{CFU} / \mathrm{gm}$. In another study, the average values of TCC at three different markets of Bangladesh were 
found as $4.7 \times 10^{4}, 4.2 \times 10^{4}$ and $5.1 \times 10^{4} \mathrm{CFU} / \mathrm{gm}$ [49] and many other studies also showed the similar result regarding TCC. The isolation of coliform bacteria also indicates probable fecal contamination and the prevalence of fecal coliform was recorded as about $33 \%$ in this study where, fecal contamination were detected in five samples $(2,7,8,11$ and 13). Presence of coliforms in broiler meat might be due to poor quality of water used for washing of meats, fecal contamination with own feces, inadequate light and air in poultry culture room, unhygienic places and personal unhygiene dinning meat processing.

\subsubsection{Presence of Escherichia coli}

E. coli can cause severe gastrointestinal tract-related complications like diarrhea, dysentery, urinary tract infections, pneumonia and even meningitis [50]. It has been recommended to be totally absent in poultry meat. Highly $E$. coli contaminated poultry meats is unfit for human consumption and considered as unhealthy. This study had revealed the presence of $E$ coli in $53 \%$ samples which is a significant matter of concern. Some studies have reported the presence of higher level of $E$. coli in chicken meat samples like 76\% [51] and 34.6\% [52]. However, some studies also showed the prevalence in chicken meat samples in lower rate like $0.4 \%$ [53], 5.6\% [54], 11.1\% [55] and 16\% [56]. The hygiene of sources, living places and environment, broiler feed and processing process with appropriate management has a great influence in minimizing the total $E$ coli count in Table 1.

Table 1. Microbial load of broiler meat.

\begin{tabular}{|c|c|c|c|c|c|c|c|c|}
\hline Samples & $\begin{array}{c}\text { Total Viable } \\
\text { Count (TVC) } \\
\text { CFU/gm }\end{array}$ & $\begin{array}{c}\text { Total Coliform } \\
\text { Count (TCC) } \\
\text { CFU/gm }\end{array}$ & $\begin{array}{l}\text { Presence of } \\
\text { fecal coliform }\end{array}$ & $\begin{array}{c}\text { Presence } \\
\text { E. coli }\end{array}$ & $\begin{array}{c}\text { Total } \\
\text { Salmonella count } \\
\text { CFU/gm }\end{array}$ & $\begin{array}{l}\text { Presence of } \\
\text { Shigella spp. }\end{array}$ & $\begin{array}{l}\text { Presence of } \\
\text { Vibrio spp. }\end{array}$ & Fungi \\
\hline Sample-1 & $3.3 \times 10^{5}$ & $2.2 \times 10^{3}$ & ND & ND & ND & ND & ND & ND \\
\hline Sample-2 & $1.6 \times 10^{6}$ & $1.9 \times 10^{4}$ & $+\mathrm{VE}$ & $+\mathrm{VE}$ & ND & ND & ND & ND \\
\hline Sample-3 & $2.3 \times 10^{4}$ & $1.6 \times 10^{3}$ & ND & ND & ND & ND & ND & ND \\
\hline Sample-4 & $3.8 \times 10^{4}$ & $2.4 \times 10^{3}$ & ND & $+\mathrm{VE}$ & ND & ND & ND & $\mathrm{ND}$ \\
\hline Sample-5 & $6.4 \times 10^{4}$ & $3.6 \times 10^{3}$ & ND & ND & ND & ND & ND & $\mathrm{ND}$ \\
\hline Sample-6 & $2.8 \times 10^{5}$ & $4.8 \times 10^{3}$ & ND & ND & $3.1 \times 10^{3}$ & ND & ND & $\mathrm{ND}$ \\
\hline Sample-7 & $5.4 \times 10^{6}$ & $3.3 \times 10^{4}$ & $+\mathrm{VE}$ & $+\mathrm{VE}$ & $4.4 \times 10^{3}$ & ND & ND & $\mathrm{ND}$ \\
\hline Sample-8 & $1.3 \times 10^{7}$ & $1.5 \times 10^{5}$ & $+\mathrm{VE}$ & $+\mathrm{VE}$ & $5.6 \times 10^{3}$ & ND & ND & $\mathrm{ND}$ \\
\hline Sample-9 & $2.1 \times 10^{5}$ & $2.8 \times 10^{4}$ & ND & ND & $5.2 \times 10^{3}$ & ND & ND & $\mathrm{ND}$ \\
\hline Sample-10 & $4.8 \times 10^{6}$ & $3.2 \times 10^{4}$ & ND & $+\mathrm{VE}$ & ND & ND & ND & $\mathrm{ND}$ \\
\hline Sample-11 & $1.1 \times 10^{6}$ & $1.3 \times 10^{5}$ & $+\mathrm{VE}$ & $+\mathrm{VE}$ & ND & ND & ND & $\mathrm{ND}$ \\
\hline Sample-12 & $2.9 \times 10^{4}$ & $2.5 \times 10^{3}$ & ND & ND & ND & ND & ND & $\mathrm{ND}$ \\
\hline Sample-13 & $3.6 \times 10^{7}$ & $6.8 \times 10^{4}$ & $+\mathrm{VE}$ & $+\mathrm{VE}$ & ND & ND & ND & $\mathrm{ND}$ \\
\hline Sample-14 & $1.8 \times 10^{6}$ & $3.9 \times 10^{4}$ & ND & ND & ND & ND & ND & $\mathrm{ND}$ \\
\hline Sample-15 & $4.2 \times 10^{5}$ & $2.8 \times 10^{4}$ & ND & $+\mathrm{VE}$ & ND & ND & ND & ND \\
\hline
\end{tabular}

$\mathrm{ND}=$ Not Detected,$+\mathrm{VE}=$ Positive. 


\subsubsection{Total Salmonella spp. Count and Presence of Shigella spp., Vibrio spp. and Fungi.}

In this study, Salmonella spp. was found $26.7 \%$ where other studies showed as $15.39 \%$ [57] and $7.41 \%$ in chicken meat [58]. The mean value of Salmonella spp. was $4.6 \times 10^{3} \mathrm{CFU} / \mathrm{gm}$, the maximum was $5.6 \times 10^{3} \mathrm{CFU} / \mathrm{gm}$ and minimum was $3.1 \times 10^{3} \mathrm{CFU} / \mathrm{gm}$. More than $25 \mathrm{~g}$ of Salmonella contaminated poultry meat is considered as unsafe for human consumption. Salmonellosis remains one of the most frequent food-borne diseases that constituting a worldwide major public health concern. The majority of food born infections may be occurred by consumption of contaminated poultry meat with Salmonella from any source in-spite of the success of Salmonella control measures implemented in food-animal production of industrialized countries [59]. The outbreaks of Shigellosis may have been associated with the consumption of several kinds of contaminated foods, milk, poultry, and some dairy products [60]. No Shigella spp. has been detected among 15 samples in this study. The result is similar with another research in which no Shigella spp. was found after evisceration [61]. Likely, no species of Vibrio has been detected in this present study. Earlier, a study has been reported a low prevalence of Vibrio spp. (0.3\%) [52]. If the Vibrio spp. frequency found at a considerable high percentage, it will indicate the alarming situation of chicken farming and for public health as well [62]. There is lack of information about the acceptable limit for fungal contaminants could be of concern to the public health [63]. Any type of fungi is totally absent in all samples, although some other studies found the fungal contamination in some fresh chicken samples [64] [65].

\subsection{Result of Biochemical Test}

Three kinds of bacteria (E. coli, Salmonella spp. and Vibrio spp.) were isolated by observing distinct morphological characteristics on selective media and further confirmed with standard Biochemical test (Table 2).

Table 2. Reaction of biochemical test.

\begin{tabular}{|c|c|c|c|c|c|c|c|c|c|c|c|c|c|c|c|c|c|}
\hline \multirow{3}{*}{ 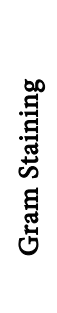 } & \multicolumn{16}{|c|}{ Biochemical reaction } & \multirow[b]{3}{*}{$\begin{array}{l}\text { Presumptive } \\
\text { Bacteria }\end{array}$} \\
\hline & \multirow[b]{2}{*}{ 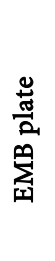 } & \multicolumn{3}{|c|}{ KIA } & \multicolumn{3}{|c|}{ MIU } & \multirow[b]{2}{*}{ 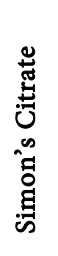 } & \multirow[b]{2}{*}{ 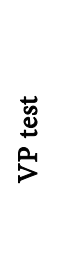 } & \multirow[b]{2}{*}{ 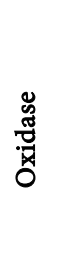 } & \multirow[b]{2}{*}{ 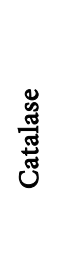 } & \multirow[b]{2}{*}{ 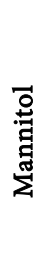 } & \multirow[b]{2}{*}{ 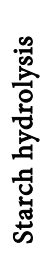 } & \multirow[b]{2}{*}{ 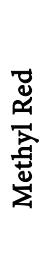 } & \multirow[b]{2}{*}{$\begin{array}{l}\mathscr{D} \\
\stackrel{0}{0} \\
\stackrel{\Xi}{0}\end{array}$} & \multirow[b]{2}{*}{ 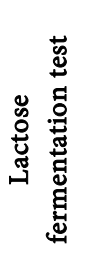 } & \\
\hline & & 荳 & 茟 & हु & 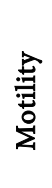 & ‡ & 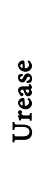 & & & & & & & & & & \\
\hline$-\mathrm{Ve}$ & + & $\mathrm{A}$ & A & + & + & + & + & - & - & - & + & A & - & + & AG & + & E. coli \\
\hline$-\mathrm{Ve}$ & - & $\mathrm{K}$ & A & G & + & + & - & + & - & + & + & + & + & + & + & - & Vibrio spp. \\
\hline$-\mathrm{Ve}$ & - & K & A & - & - & - & - & - & - & - & + & - & - & + & + & - & Shigella spp. \\
\hline$-\mathrm{Ve}$ & - & $\mathrm{K}$ & A & G & + & - & + & + & - & - & - & $\mathrm{A}$ & - & + & - & - & Salmonella spp. \\
\hline
\end{tabular}

$\mathrm{K}=$ Alkaline $, \mathrm{A}=\mathrm{Acid}, \mathrm{G}=\mathrm{Gas}, \mathrm{AG}=\mathrm{Acid}$ and Gas,$+=$ Presence,$-=$ Absence . 


\subsection{Antibiotic Resistance Pattern}

Resistance against commercially available commonly used antibiotics has been observed in bacteria present in broiler since the introduction of these antimicrobial agents in poultry. The rise in antibiotic resistance has been reported in the past two decades in many countries including Bangladesh [66]. Based on the susceptibility to antibiotics, the bacteria were categorized into three groups-sensitive, intermediate, and resistance. Total 20 isolates (10 E. coli and 10 Salmonella spp.) were randomly selected for antibiotic susceptibility test.

In this study, E. coli showed highly resistance to Ampicillin (80\%) and Amoxicillin (70\%). Where, $40 \%$ were resistance to Nalidixic acid and Erythromycin. About $90 \%$ E. coli showed sensitivity to Ciprofloxacin, $80 \%$ to Gentamicin, $60 \%$ to Tetracycline and $50 \%$ to Norfloxacin (Figure 2). The results strengthen the earlier observations of some study where it was found that the E. coli isolated from broiler were sensitive to Azithromycin, Ciprofloxacin, Norfloxacin and Gentamicin and resistant to Amoxicillin and Erythromycin. The possessions of such factors by the $E$. coli isolates signify the fact that the organisms might have gained the resistance property due to the unsystematic use of antibiotics [67]. Salmonella spp. showed 100\% resistance to Ampicillin, 90\% resistance to Amoxicillin and highly sensitive to Ciprofloxacin (80\%). About 50\% were resistance to Nalidixic Acid and Norfloxacin whereas sensitive to Erythromycin (60\%) and Gentamicin (50\%) (Figure 3). Some others earlier study also revealed that

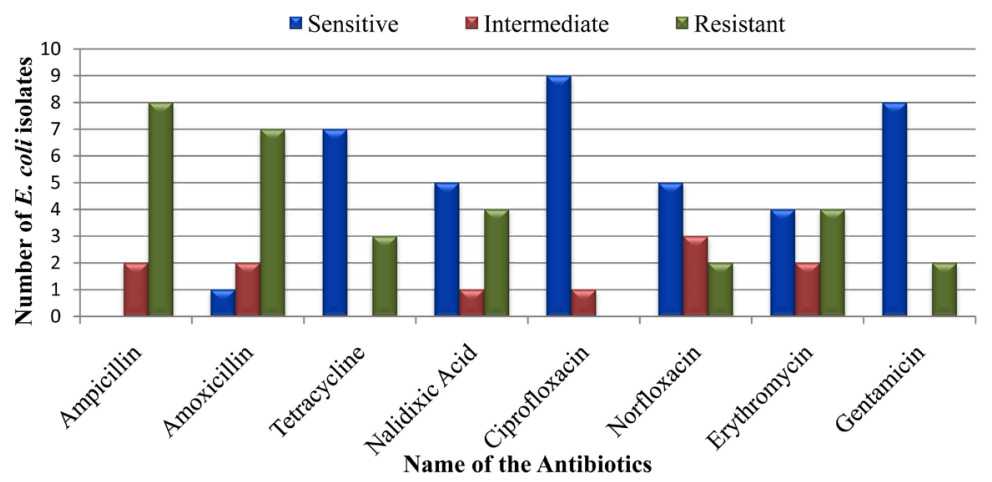

Figure 2. Antibiotic resistance pattern of Escherichia coli.

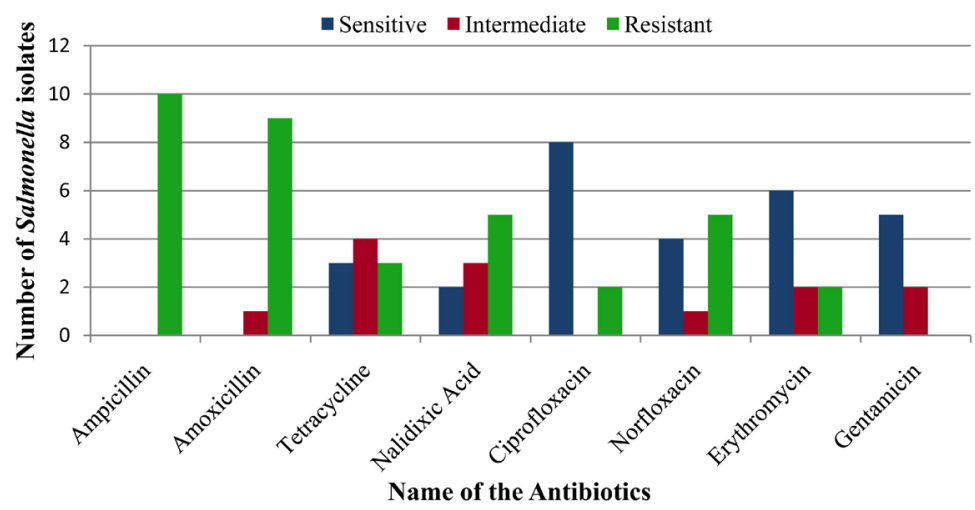

Figure 3. Antibiotic resistant pattern of Salmonella spp. 
Salmonella spp. were sensitive to Ciprofloxacin, Gentamicin and Azithromycin [68] [69] and resistant to Erythromycin and Amoxicillin [70] [71]. Potential drug resistant pathogens in normal broilers may be a serious public health concern.

\subsection{Evaluation of Antibacterial Activity of Azadirachta indica against Some Multidrug Resistance Escherichia coli and Salmonella spp.}

The zone of inhibition of negative (30\% methanol, $40 \%$ methanol, 30\% ethanol, $40 \%$ ethanol, DMSO) control of plant extract and positive control (Ciprofloxacin) with and their comparison is presented in (Table 3). The above result specified the antimicrobial activity of extract against Escherichia coli and salmonella spp. depending on the nature of the active ingredients present in the extracts and their capacity of diffusion into agar medium. Antibacterial activities of methanolic and ethanolic plant extract (both $30 \%$ and $40 \%$ ) were significant against $E$. coli. The average zone of inhibition of methanolic and ethanolic extract were 13 and 14.33 respectively, where $40 \%$ ethanolic plant extract was more potent than the $30 \%$ (Figure 4). No zone of inhibition was formed against isolated Salmonella spp.

Table 3. Antibacterial activity of Azadirachta indica plant extract.

\begin{tabular}{|c|c|c|c|c|c|c|c|}
\hline \multirow{3}{*}{ Parameters } & \multirow{3}{*}{ Used as } & \multicolumn{6}{|c|}{ Zone of inhibition ( $\mathrm{mm}$ in diameter) } \\
\hline & & \multicolumn{3}{|c|}{ E. coli } & \multicolumn{3}{|c|}{ Salmonella } \\
\hline & & E. coli-1 & E. coli-2 & E. coli-3 & Salmonella-1 & Salmonella-2 & Salmonella-3 \\
\hline $30 \%$ Methanol & $\begin{array}{l}\text { Negative } \\
\text { control }\end{array}$ & NA & NA & NA & NA & NA & NA \\
\hline $40 \%$ Methanol & $\begin{array}{l}\text { Negative } \\
\text { control }\end{array}$ & NA & NA & NA & NA & NA & NA \\
\hline $30 \%$ Ethanol & $\begin{array}{c}\text { Negative } \\
\text { control }\end{array}$ & NA & NA & NA & NA & NA & NA \\
\hline $40 \%$ Ethanol & $\begin{array}{l}\text { Negative } \\
\text { control }\end{array}$ & NA & NA & NA & NA & NA & NA \\
\hline DMSO & $\begin{array}{l}\text { Negative } \\
\text { control }\end{array}$ & NA & NA & NA & NA & NA & NA \\
\hline Ciprofloxacin & $\begin{array}{l}\text { Standard } \\
\text { Antibiotic }\end{array}$ & 26 & 23 & 25 & 19 & 16 & 21 \\
\hline $\begin{array}{l}\text { 30\% Methanolic } \\
\text { Plant extract }\end{array}$ & $\begin{array}{l}\text { Experimental } \\
\text { solution }\end{array}$ & 12 & 11 & 13 & NA & NA & NA \\
\hline $\begin{array}{c}40 \% \text { Methanolic } \\
\text { Plant extract }\end{array}$ & $\begin{array}{l}\text { Experimental } \\
\text { solution }\end{array}$ & 14 & 12 & 16 & NA & NA & NA \\
\hline $\begin{array}{c}30 \% \text { Ethanolic } \\
\text { Plant extract }\end{array}$ & $\begin{array}{l}\text { Experimental } \\
\text { solution }\end{array}$ & 15 & 10 & 12 & NA & NA & NA \\
\hline $\begin{array}{l}40 \% \text { Ethanolic } \\
\text { Plant extract }\end{array}$ & $\begin{array}{l}\text { Experimental } \\
\text { solution }\end{array}$ & 18 & 14 & 17 & NA & NA & NA \\
\hline
\end{tabular}

N/A = No Activity. 


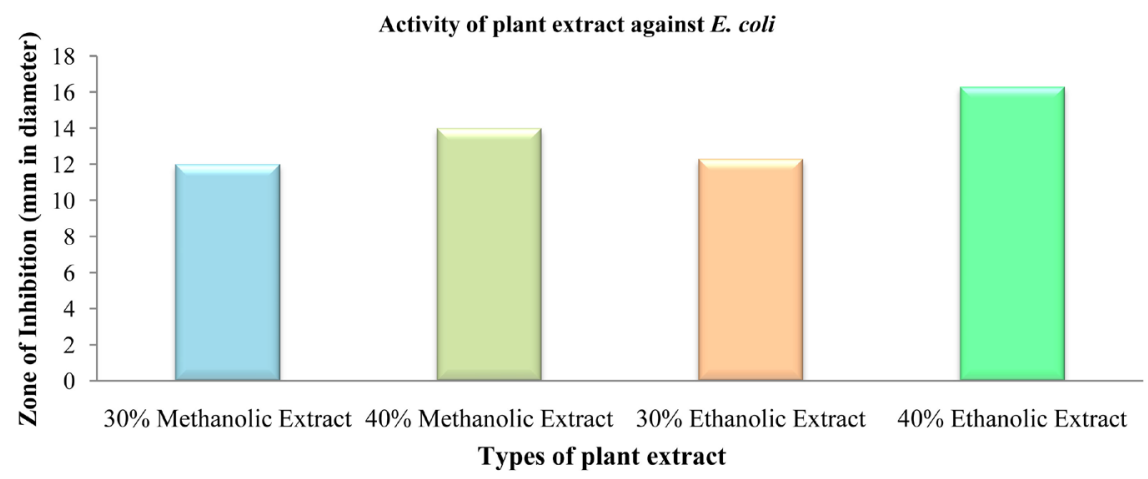

Figure 4. Average zone of inhibition of methanolic and ethanolic plant extract with different concentrations against Escherichia coli.

A previous study found the average zone of inhibition of methanolic extract of Azadirachta indica against Escherichia coli was $7.5 \mathrm{~mm}$ [72]. The zone of inhibition against $E$. coli in both methanolic and ethanolic extract was not found by another research [73]. But Zone of inhibition of methanolic extract of same plants against Salmonella spp. was reported as $10-20 \mathrm{~mm}$ [74]. Another study evaluated the zone of inhibition with different concentrations of methanolic plant extract were $20 \mathrm{~mm}, 22 \mathrm{~mm}, 24 \mathrm{~mm}$ and $21 \mathrm{~mm}$ in diameter against $E$. coli, where $18 \mathrm{~mm}, 22 \mathrm{~mm}, 20 \mathrm{~mm}$ and $21 \mathrm{~mm}$ in diameter against Salmonella spp. [75].

\subsection{Assessment of Public Health Impact of Broiler Meat}

The total respondents were divided into five groups based on age range- -5 to 15 , 16 to 30,31 to 40,40 to 50 and above 50 years old (Table 4). Each group had 40 male and 40 female respondents (Table 4). Total 300 (75\%) people eat broiler meat among the total respondents, where 150 (50\%) were females and 150 (50\%) were males. The educational status of the respondent showed that, about $8 \%$ were illiterate, $10 \%$ completed primary level, $21 \%$ passed up to secondary level, $32 \%$ were higher secondary level and $35 \%$ were in graduation level (Table 5).

On the basis of family income, the respondents were divided into five socio-economic groups, like poor (15.75\%), lower middle class $(23.5 \%)$, middle class (49.25\%), upper middle class (6.75\%) and higher class (4.75\%) (Table 6). Most of the female respondents in this study were domestic worker (34.5\%). The major source of family income among these respondents were day laborer (18\%) and businessman (18\%), rest of them were private service holder $(14.75 \%)$ and government service holder (14.75\%) (Figure 5).

In this study, it was found that consumption of broiler meat largely varies with the socio-economic status of respondents (Table 7). Depending on economic status, most of the poor people $(\mathrm{N}=31,49.20 \%)$ ate broiler meat at least one day in a week where very few people of upper middle class $(\mathrm{N}=9,21.95 \%)$ and higher class $(\mathrm{N}=2,4.88 \%)$ ate occasionally, and majority of last two groups never eat broiler meat $(\mathrm{N}=12,44.44 \%)$ and $(\mathrm{N}=17,89.47 \%$ respectively).Large number of broiler meat consumer were middle classes and lower middle classes 
Table 4. Frequency distribution of the respondents of this study.

\begin{tabular}{ccccccccc}
\hline Parameters & $\begin{array}{c}\text { Total } \\
\text { respondents }\end{array}$ & $\begin{array}{c}\text { Eat } \\
\text { broiler } \\
\text { meat }\end{array}$ & $\begin{array}{c}\text { Never } \\
\text { eat } \\
\text { broiler } \\
\text { meat }\end{array}$ & $\begin{array}{c}\text { Age } \\
\text { between } \\
5-15 \\
\text { years }\end{array}$ & $\begin{array}{c}\text { Age } \\
\text { between } \\
16-30 \\
\text { years }\end{array}$ & $\begin{array}{c}\text { Age } \\
\text { between } \\
31-40 \\
\text { years }\end{array}$ & $\begin{array}{c}\text { Age } \\
\text { between } \\
41-50 \\
\text { years }\end{array}$ & $\begin{array}{c}\text { Age } \\
\text { above } \\
50 \text { years }\end{array}$ \\
\hline $\begin{array}{c}\text { Number of } \\
\text { respondents }\end{array}$ & 400 & 300 & 100 & 80 & 80 & 80 & 80 & 80 \\
Female & $200(50 \%)$ & 150 & 50 & 40 & 40 & 40 & 40 & 40 \\
Male & $200(50 \%)$ & 150 & 50 & 40 & 40 & 40 & 40 & 40 \\
\hline
\end{tabular}

Table 5. Educational status of subjected people.

\begin{tabular}{cccccc}
\hline & \multicolumn{5}{c}{ Level of education } \\
\cline { 2 - 6 } Parameters & Illiterate & $\begin{array}{c}\text { Up-to } \\
\text { primary level }\end{array}$ & $\begin{array}{c}\text { Up-to } \\
\text { secondary level }\end{array}$ & $\begin{array}{c}\text { Up-to higher } \\
\text { secondary level }\end{array}$ & $\begin{array}{c}\text { Up-to } \\
\text { graduation level }\end{array}$ \\
\hline Female & 15 & 13 & 34 & 85 & 53 \\
Male & 17 & 25 & 45 & 34 & 79 \\
Total & 32 & 38 & 79 & 119 & 132 \\
\hline
\end{tabular}

Table 6. Socio-economic condition of the people.

\begin{tabular}{cccccc}
\hline & \multicolumn{5}{c}{ Socio-economic condition } \\
\cline { 2 - 6 } Parameters & Poor & $\begin{array}{c}\text { Lower } \\
\text { middle class }\end{array}$ & $\begin{array}{c}\text { Middle } \\
\text { class }\end{array}$ & $\begin{array}{c}\text { Upper } \\
\text { middle class }\end{array}$ & $\begin{array}{c}\text { Higher } \\
\text { class }\end{array}$ \\
\hline $\begin{array}{c}\text { Family income } \\
\text { per month (taka) } \\
\text { Total respondents }\end{array}$ & Below 10,000 & $10,000-20,000$ & $21,000-30,000$ & $31,000-40,000$ & Above 40,000 \\
Percent & $15.75 \%$ & $23.5 \%$ & $49.25 \%$ & $6.75 \%$ & 19 \\
\hline
\end{tabular}

Table 7. Broiler meat intake pattern.

\begin{tabular}{|c|c|c|c|c|c|c|}
\hline \multirow[b]{2}{*}{ Parameters } & \multicolumn{5}{|c|}{ Broiler meat intake pattern } & \multirow{2}{*}{$\begin{array}{c}\text { Never eat } \\
\text { broiler } \\
\text { meat }\end{array}$} \\
\hline & Occasionally & Frequently & $\begin{array}{l}\text { At least } 5 \\
\text { days in a } \\
\text { week }\end{array}$ & $\begin{array}{c}\text { At least } \\
2 \text { - } 4 \text { days } \\
\text { in a week }\end{array}$ & $\begin{array}{c}\text { At least } \\
1 \text { day } \\
\text { in a week }\end{array}$ & \\
\hline Poor & $8(12.7 \%)$ & $6(9.52 \%)$ & $2(3.17 \%)$ & $13(20.63 \%)$ & $31(49.20 \%)$ & $3(4.76 \%)$ \\
\hline $\begin{array}{c}\text { Lower } \\
\text { middle class }\end{array}$ & $13(13.83 \%)$ & $18(19.15 \%)$ & None & $44(46.81 \%)$ & $11(11.70 \%)$ & $8(8.51 \%)$ \\
\hline $\begin{array}{l}\text { Middle } \\
\text { class }\end{array}$ & $9(4.57 \%)$ & $85(43.15 \%)$ & $6(3.04 \%)$ & $14(7.10 \%)$ & $23(11.68 \%)$ & $60(30.46 \%)$ \\
\hline $\begin{array}{c}\text { Upper } \\
\text { middle class }\end{array}$ & $9(33.33 \%)$ & $6(22.22 \%)$ & None & None & None & $12(44.44 \%)$ \\
\hline $\begin{array}{l}\text { Higher } \\
\text { class }\end{array}$ & $2(10.53 \%)$ & None & None & None & None & $17(89.47 \%)$ \\
\hline $\begin{array}{c}\text { Total } \\
\text { (Percent) }\end{array}$ & $41(13.67 \%)$ & $115(38.33 \%)$ & $8(2.67 \%)$ & $71(23.67 \%)$ & $65(21.67 \%)$ & 100 \\
\hline
\end{tabular}


where most of the mate broiler meat frequently $(\mathrm{N}=85,73.91 \%)$ and At least 2 4 days in a week $(\mathrm{N}=44,61.97 \%)$. Very few people of middle and lower middle classes ate broiler meat at least 5 days in a week (Figure 6).

$\mathrm{BMI}$ is an important consideration for evaluating the health condition of particular people. Various BMI had been observed among the responders who ate broiler meat or not. By considering various BMI group, it was found that, overweight (male $24.67 \%$, female $22.67 \%$ ) and obesity (male $32 \%$, female $8 \%$ ) of the responders who ate broiler meat were high in comparison with overweight (male $10 \%$, female $16 \%$ ) and obesity (male $8 \%$, female $6 \%$ ) of responders who never ate broiler meat (Figure 7).

Some common diseases such as food allergy, overweight, obesity, high blood pressure, and diabetes were considered to determine the possible correlation with consumption of broiler meat. Food allergy is allergic reaction of food includes fish, shellfish, peanuts, tree nuts, walnuts, etc., but not directly related to broiler meat. In this study, it was found that the occurrence of food allergy relatively high among the people who never ate broiler (male 32\%, female 12\%) compare to the people who ate broiler meat (male 23.3\%, female 9.3\%), whereas, in case of other diseases, it was vice versa. Among the broiler meat consumer, overweight, obesity and high blood pressure were found in elevated rate than any other diseases both in male and female. Male who eat broiler meat had high blood pressure, high cholesterol level, digestive disorders, constipation and diabetes in alarming percentage with $35.3 \%, 22.7 \%, 18.7 \%, 24 \%$ and $7.3 \%$ respectively whereas male who never eat broiler meat had this diseases in percentage with $16 \%, 10 \%, 14 \%, 6 \%$ and $4 \%$ in some respect. Surprisingly, it is a matter of great concern that, $3.3 \%$ male who eat broiler meat found having benign fat deposition like tiny tumor but this disease did not found in male and female who never eat broiler meat (Figure 8).

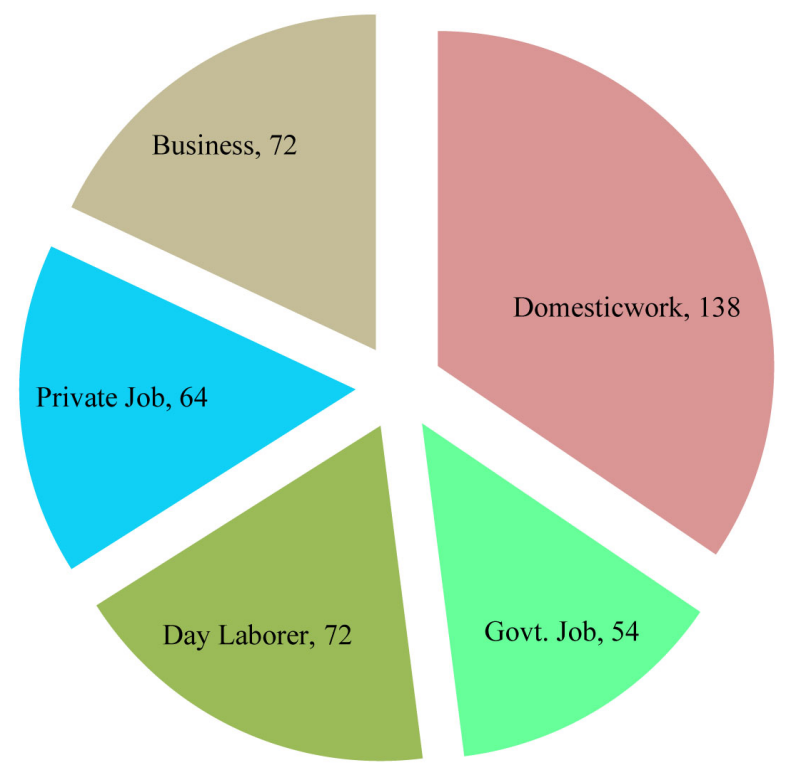

Figure 5. Source of family income of the respondents. 


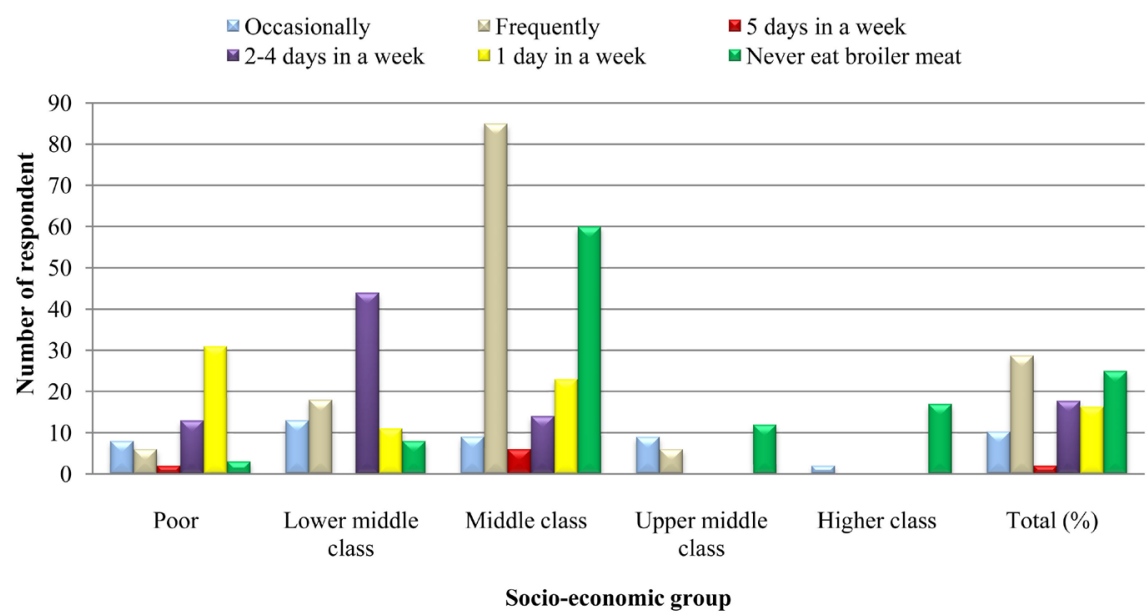

Figure 6. Broiler meat intake pattern.

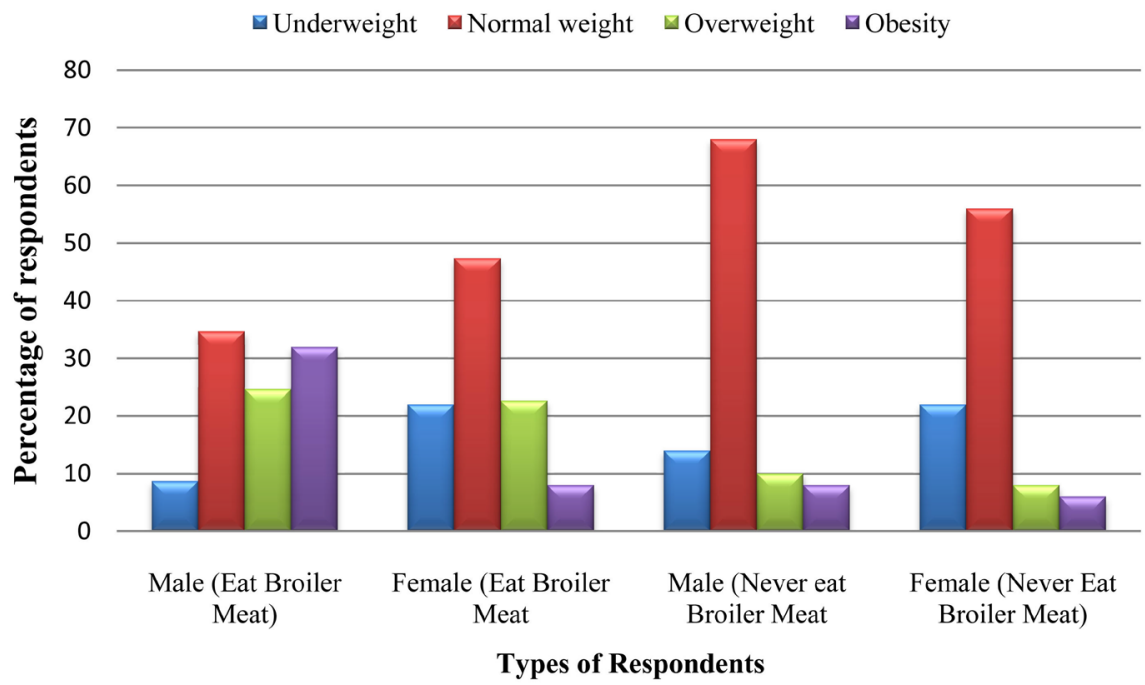

Figure 7. Various health condition of broiler meat consumer according to BMI.

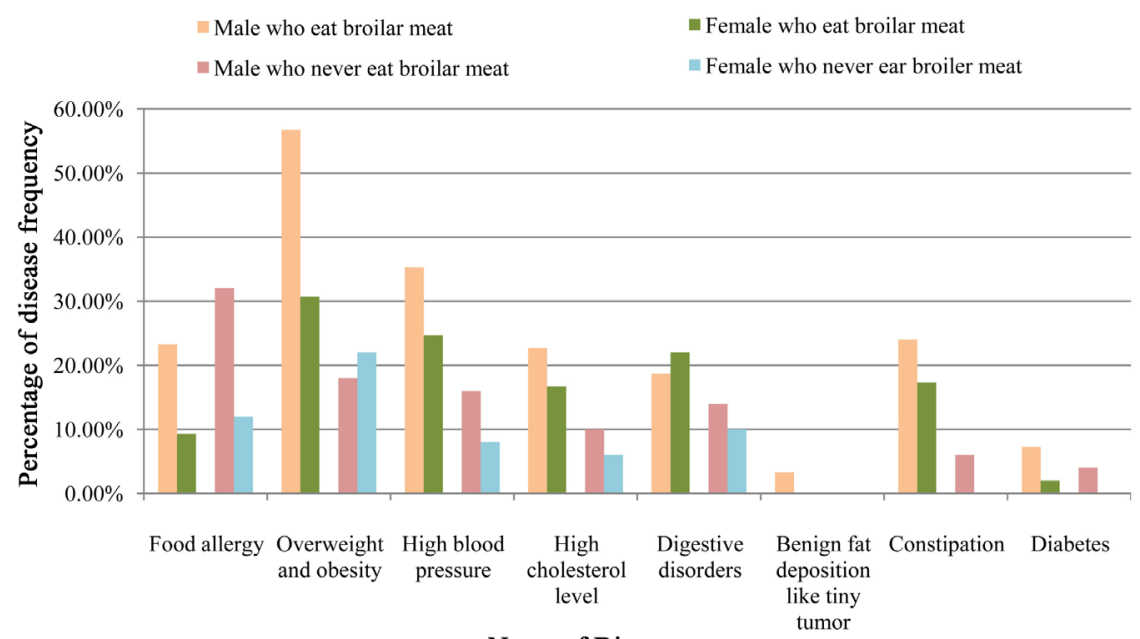

Name of Diseases

Figure 8. Comparison of disease frequency between who eat broiler meat and never eat broiler meat (male and female). 


\section{Conclusion}

The present study demonstrated that the contamination of poultry and poultry products should be prevented during handling, slaughtering and processing to protect the public from infections and diseases. Present data also indicated that the viable count of microorganisms causing public hazards is also appropriate for analysis. Due to increasing density of poultry farms and infectious diseases in poultry caused by pathogenic bacteria, the healthy development of the poultry industry is facing serious threat. Therefore, application of hygienic measurements appears to be important to reduce the contamination of bacteria after processing of meat. The presence of E. coli and Salmonella demonstrates a potential health risk since the organisms are pathogenic and give warning signal for the possible occurrence of food borne intoxication. The need for microbial assessment of fresh meats for human consumption is emphasized and recommended to reduce possible hazard. Sensible use of antibiotics should be considered in broiler production since many strains get resistant to common antibiotics. The leaf extract of Azadirachta indica showed potent antibacterial activity against $E$. coli. It is recommended to isolate and separate the bioactive compounds responsible for this antibacterial activity and to apply such medicinal plants to minimize bacterial contamination in broiler meat.

\section{Conflicts of Interest}

The authors declare no conflicts of interest regarding the publication of this paper.

\section{References}

[1] Taha, F.A. (2003) The Poultry Sector in Middle-Income Countries and Its Feed Requirements: The Case of Egypt. Outlook Report No. WRS03-02. Economic Research Service, USDA, Washing DC.

[2] Yashoda, K.P., Sachindra, N.M., Sakhare, P.Z. and Rao, D.N. (2001) Microbiological Quality of Broiler Chicken Carcasses Processed Hygienically in a Small Scale Poultry Processing Unit. Journal of Food Quality, 24, 249-259. https://doi.org/10.1111/j.1745-4557.2001.tb00606.x

[3] Ahmed, A.M., Shimabukuro, H. and Shimamoto, T. (2009) Isolation and Molecular Characterization of Multidrug-Resistant Strains of Escherichia coli and Salmonella from Retail Chicken Meat in Japan. Journal of Food Science, 74, M405-M410. https://doi.org/10.1111/j.1750-3841.2009.01291.x

[4] Adu-Gyamfi, A., Torgby-Tetteh, W. and Appiah, V. (2012) Microbiological Quality of Chicken Sold in Accra and Determination of D10-Value of E. coli. Food and Nutrition Sciences, 3, 693-698. https://doi.org/10.4236/fns.2012.35094

[5] Mead, G.C. (1989) Hygiene Problems and Control of Process Contamination. In: Mead, G.C., Ed., Processing of Poultry, Elsevier Science Publishers Ltd., Amsterdam, 183-220. https://doi.org/10.1007/978-1-4615-2059-7_6

[6] Živković, J. (2001) Higijena i tehnologija mesa. Veterinarsko-sanitarni nadzor životinja za klanje i mesa. I. dio. II. dopunjeno izdanje. Uredio i dopunio M. Hadžiosmanović. Veterinarski fakultet Sveučilišta u Zagrebu. 
[7] Capita, R., Calleja, C.A., Pietro, M., Fernandez, M., Del, C.G. and Moreno, B. (2002) Incidence and Pathogenicity of Yersinia spp. Isolates from Poultry in Spain. Food Microbiology, 19, 295-301. https://doi.org/10.1006/fmic.2002.0492

[8] Velge, P., Cloeckeart, A. and Barrow, P. (2005) Emergence of Salmonella Epidemics: The Problem Related to Salmonella Enteric Serotype Enteritidis and Multiple Antibiotic Resistance in Other Major Serotypes. Veterinary Research, 36, 267-288. https://doi.org/10.1051/vetres:2005005

[9] Panisello, P.J., Rooney, R., Quantick, P.C. and Stanwell, S.R. (2000) Application of Food Borne Disease Outbreak Data in the Development and Maintenance of HACCP Systems. International Journal Food Microbiology, 59, 221-234. https://doi.org/10.1016/S0168-1605(00)00376-7

[10] Javadi, A. and Safarmashaei, S. (2011) Study of Enterobacteriaceae Contamination Level in Premises of Poultry Slaughterhouse with HACCP System. Journal of Animal and Veterinary Advances, 10, 2163-2166. https://doi.org/10.3923/javaa.2011.2163.2166

[11] Abd-Elghany, S.M., Sallam, K.I., Abd-Elkhalek, A. and Tamura, T. (2015) Occurrence, Genetic Characterization and Antimicrobial Resistance of Salmonella Isolated from Chicken Meat and Giblets. Epidemiology \& Infection, 143, 997-1003. https://doi.org/10.1017/S0950268814001708

[12] Abgottspon, H., Stephan, R., Bagutti, C., Brodmann, P., Hächler, H. and Zurfluh, K. (2014) Characteristics of Extended-Spectrum Cephalosporin-Resistant Escherichia coli Isolated from Swiss and Imported Poultry Meat. Journal of Food Protection, 77, 112-115. https://doi.org/10.4315/0362-028X.JFP-13-120

[13] Hossain, M., Hoda, N., Hossen, M.J., Mahmudul Hasan, M., Rahman, S.M.E. and Lutful Kabir, S.M. (2015) Assessment of Bacterial Load of Poultry Meat Used at Dining Hall of Bangladesh Agricultural University Campus. Asian Journal of Medical and Biological Research, 1, 9-16. https://doi.org/10.3329/ajmbr.v1i1.25492

[14] ICMSF (International Commission on Microbiological Specifications for Foods) (2002) Microorganisms in Foods 7. Microbiological Testing in Food Safety Management. Kluwer Academic/Plenum Publishers, New York.

[15] Johnson, J.R., Kuskowski, M.A., Smith, K., O’Bryan, T.T. and Tatini, S. (2005) Antimicrobial-Resistant and Extraintestinal Pathogenic Escherichia coli in Retail Foods. The Journal of Infectious Diseases, 191, 1040-1049. https://doi.org/10.1086/428451

[16] Daini, O.A., Ogbulo, O.D. and Ogunledun, A. (2005) Quinolones Resistance and R-Plasmids of Some Gram Negative Enteric Bacilli. African Journal of Clinical and Experimental Microbiology, 6, 14-20. https://doi.org/10.4314/ajcem.v6i1.7394

[17] Sackey, B.A., Mensah, P., Collison, E. and Dawson, E.S. (2001) Campylobacter, Salmonella, Shigella and Escherichia coli in Live and Dressed Poultry from Metropolitan Accra. International Journal of Food Microbiology, 71, 21-28. https://doi.org/10.1016/S0168-1605(01)00595-5

[18] Gill, C.O. and Badoni, M. (2005) Recovery of Bacteria from Poultry Carcasses by Rinsing, Swabbing or Excision of Skin. Food Microbiology, 22, 101-107. https://doi.org/10.1016/j.fm.2004.04.005

[19] Behravesh, B. (2008) Salmonellosis, in Control of Communicable Diseases Manual. 19th Edition, American Public Health Association, Washington DC, 535-540.

[20] Bhaisare, D.B., Thyagarajan, D., Churchil, R.R. and Punniamurthy, N. (2014) Bacterial Pathogens in Chicken Meat: Review. International Journal of Life Sciences Research, 2, 1-7. 
[21] Aho, M. and Hirn, J. (1988) Prevalence of Campylobacteria in the Finnish Broiler Chicken Chain from the Producer to the Consumer. Acta Veterinaria Scandinavica, 29, 451-462.

[22] Northcutt, J.K. and Berrange, M.E. (2006) Influence of Chicken Transport Cage-Washing System on Waste Water Characteristic and Bacteria Recovery from Cage Flooring. The Journal of Applied Poultry Research, 15, 457-463. https://doi.org/10.1093/japr/15.3.457

[23] McCrea, B.A., Tonooka, K., Vanworth, H.C., Boggs, C.L., et al. (2006) Prevalence of Campylobacter and Salmonella Species on Farm after Transport and at Processing in Specialty Market Poultry. Poultry Science, 85, 136-143. https://doi.org/10.1093/ps/85.1.136

[24] Keener, K.M., Bashor, M.P., Curtis, P.A., Sheldon, B.W. and Kathariou, S. (2004) Comprehensive Review of Campylobacter and Poultry Processing. Comprehensive Reviews in Food Science and Food Safety, 3, 105-116. https://doi.org/10.1111/j.1541-4337.2004.tb00060.x

[25] Marangoni, F., Corsello, G., Cricelli, C., Ferrara, N., Ghiselli, A., Lucchin, L. and Poli, A. (2015) Role of Poultry Meat in a Balanced Diet Aimed at Maintaining Health and Wellbeing: An Italian Consensus Document. Food \& Nutrition Research, 59, 27606. https://doi.org/10.3402/fnr.v59.27606

[26] Ahmad, I., Memood, Z. and Mohammad, F. (1998) Screening of Some Indian Medicinal Plants for Their Antimicrobial Properties. Journal of Ethnopharmacology, 62, 183-193. https://doi.org/10.1016/S0378-8741(98)00055-5

[27] Cunha, B.A. (2001) Antibiotic Side Effects. Medical Clinics of North America, 85, 149-185. https://doi.org/10.1016/S0025-7125(05)70309-6

[28] Vermani, K. and Garg, S. (2002) Herbal Medicines for Sexually Transmitted Diseases and AIDS. Journal of Ethnopharmacology, 80, 49-66. https://doi.org/10.1016/S0378-8741(02)00009-0

[29] Chaisa, W. and Gritsanapan, W. (2013) Quality Assessment and Scavenging Activity of Siamese Neem Flower Extracty. Natural Product Research, 27, 394-401. https://doi.org/10.1080/14786419.2012.706295

[30] Sithisarn, P., Supabphol, R. and Gritsanapan, W. (2006) Comparison of Free Radical Scavenging Activity of Siamese Neem Tree (Azadirachta indica A. Juss var. siamensis Valeton) Leaf Extracts Prepared by Different Methods of Extraction. Medical Principles and Practice, 15, 219-222. https://doi.org/10.1159/000092185

[31] Sithisarn, P., Supabphol, R. and Gritsanapan, W. (2005) Antioxidant Activity of Siamese Neem Tree (VP1209). Journal of Ethnopharmacology, 99, 109-112. https://doi.org/10.1016/j.jep.2005.02.008

[32] Paul, R., Prasad, M. and Sah, N.K. (2011) Anticancer Biology of Azadirachta indica L. Neem: A Mini Review. Cancer Biology \& Therapy, 12, 467-476. https://doi.org/10.4161/cbt.12.6.16850

[33] Bajaj, S. and Srinivasan, B.P. (1999) Investigation into the Anti-Diabetic Activity of Azadirachta indica. Indian Journal of Pharmacology, 31, 138-141.

[34] Hafiza, R.E. (1997) Peptide Antibiotics. The Lancet, 349, 418-422.

[35] Kumar, S., Srivastava, A. and Shukla, Y.N. (2000) Recent Development in Plant Derived Antimicrobial Constituents: A Review. Journal of Medicinal and Aromatic Plant Sciences, 22, 349-405.

[36] Gelli, A., Becquey, E., Ganaba, R., Headey, D., Hidrobo, M., Huybregts, L., Verhoef, H., Kenfack, R., Zongouri, S. and Guedenet, H. (2017) Improving Diets and Nutri- 
tion through an Integrated Poultry Value Chain and Nutrition Intervention (SELEVER) in Burkina Faso: Study Protocol for a Randomized Trial. Trials, 18, 412. https://doi.org/10.1186/s13063-017-2156-4

[37] Lohman, T., Roche, A.F. and Martorell, R. (1988) Anthropometric Standardization Reference Manual. Human Kinetics Publication, Chicago.

[38] Cole, T.J., Flegal, K.M., Nicholls, D. and Jackson, A.A. (2007) Body Mass Index Cut Offs to Define Thinness in Children and Adolescents: International Survey. BMJ, 335, 194-198. https://doi.org/10.1136/bmj.39238.399444.55

[39] Jeemon, P., Prabhakaran, D., Mohan, V., Thankappan, K.R., Joshi, P.P., Ahmed, F., Chaturvedi, V. and Reddy, K.S. (2009) Double Burden of Underweight and Overweight among Children (10 - 19 Years of Age) of 149 Employees Working in Indian Industrial Units. The National Medical Journal of India, 22, 172-176.

[40] ISO (1995) Recommendation of the Meeting of the Subcommittee, International Organization for Standardization, on Meat and Meat Products. ISO/TC-36/Sc-6, The Netherlands, 10-18.

[41] Gomez, K.A. and Gomez, A.A. (1984) Statistical Procedures for Agricultural Research. 2nd Edition, John Wiley and Sons, London.

[42] International Commission on Microbiological Specifications for Foods (ICMSF) (1985) Microorganism in Foods; Samples for Microbiological Analysis: Principles and Specific Applications, Recommendation of the International Commission on Microbiological Specification for Foods. Association of Microbiological Societies, University of Toronto Press, Toronto.

[43] Krieg, N.R., Holt, J.G., Sneath, P.H.A., Staley, J.T. and Williams, S.T. (1994) Bergey's Manual of Determinative Bacteriology. 9th Edition, Williams \& Wilkins, Baltimore.

[44] Sneath, P.H., Mair, N.S., Sharpe, M.E. and Holt, J.G. (1986) Bergey's Manual of Systematic Bacteriology. Volume 2, Williams \& Wilkins, Baltimore.

[45] Kirby-Bauer, M. (1997) Disk Diffusion Susceptibility Testing. Newsletter of Animal Disease Diagnostic Laboratory. http://www.addl.purdue.edu/newsletters/1997/spring/dds.shtml

[46] Datta, S., Akter, A., Shah, I.G., Fatema, K., Islam, T.H., Bandyopadhyay, A., Khan, Z. and Biswas, D. (2012) Microbiological Quality Assessment of Raw Meat and Meat Products and Antibiotic Susceptibility of Isolated Staphylococcus aureus. Agriculture, Food and Analytical Bacteriology, 2, 187-194.

[47] Chowdhuri, A., et al. (2011) Study on Isolation and Identification of Salmonella and Escherichia coli from Different Poultry Feeds of Savar Region of Dhaka, Bangladesh. Journal of Scientific Research, 3, 403-411. https://doi.org/10.3329/jsr.v3i2.7128

[48] Ramya, P., Tirupathi Reddy, E., Vijaya Kumar, A. and Krishnaiah, N. (2015) Study on Microbiological Analysis of Raw Meat. International Journal of Institutional Pharmacy and Life Sciences, 5, 1-9.

[49] Mahmudul Hasan, M., Lutful Kabir, S.M., Hoda, N. and Mansurul Amin, M. (2015) Assessment of Microbial Load in Marketed Broiler Meat at Mymensingh District of Bangladesh and Its Public Health Implications. Research in Agriculture, Livestock and Fisheries, 2, 87-95. https://doi.org/10.3329/ralf.v2i1.23033

[50] Johnson, T.J., Siek, K.E., Johnson, S.J. and Nolan, L.K. (2006) DNA Sequence of a ColV Plasmid and Prevalence of Selected Plasmid Encoded Virulence Genes among Avian E. coli Strains. Journal of Bacteriology, 188, 745-758. 
https://doi.org/10.1128/JB.188.2.745-758.2006

[51] Iroha, I.R., Ugbo, E.C., Illang, D.C., Oji, A.E. and Ayogu, T.E. (2011) Bacterial Contamination of Raw Meat Sold in Abakaliki, Ebonyi State, Nigeria. Journal of Public Health and Epidemiology, 3, 49-53.

[52] Munir, E.H., Khalifa, K.A. and Mohammed, A.M. (2014) Status of Food Safety Due to Bacterial Contaminants of Poultry Meat and Poultry Products in Khartoum State. Journal of Scientific Research \& Reports, 3, 1897-1904. https://doi.org/10.9734/JSRR/2014/9395

[53] Syne, S.M., Ramsubhag, A. and Adesiyun, A.A. (2015) Microbiological Quality of Popular Locally Processed Meats Sold in Retail Outlets in Trinidad, West Indies. Journal of Food Protection, 2, 240-476. https://doi.org/10.4315/0362-028X.JFP-14-154

[54] Tavakoli, H.R. and Riazipour, M. (2008) Microbiological Quality of Cooked Meat Foods in Tehran University's Restaurants. Pakistan Journal of Medical Sciences, 24, 595-599.

[55] Adesiji, Y.O., Alli, O.T., Adekanle, M.A. and Jolayemi, J. (2011) Prevalence of Arcobacter, Escherichia coli, Staphylococcus aureus and Salmonella Species in Retail Raw Chicken, Pork, Beef and Goat Meat in Osogbo, Nigeria. The Journal of Biomedical Research, 3, 8-12. https://doi.org/10.4314/sljbr.v3i1.66644

[56] Ukut, I.O.E., Okonko, I.Q., Ikpoh, I.S., Nkang, A.O., Udeze, A.O., Babalona, T.A., Meheja, O.K. and Fajobi, E.A. (2010) Assessment of Bacteriological Quality of Fresh Meats Sold in Calabar Metropolis, Nigeria. Electronic Journal of Environmental, Agricultural and Food Chemistry, 9, 89-100.

[57] Kozačinski, L., Hadžiosmanović, M. and Zdolec, N. (2006) Microbiological Quality of Poultry Meat on the Croatian Market. Veterinarski Arhiv, 76, 305-313.

[58] Gyamfi, A.A., Wellington, T.T. and Appia, V. (2012) Microbiological Quality of Chicken Sold in Accra and Determination of D10 Value of E. coli. Food and Nutrition Sciences, 3, 693-698.

[59] Peixe, L., de Microbiologia, L., de Farmácia, F., do Porto, U. and Viterbo, R.J. (2015) Salmonellosis. The Role of Poultry Meat. Clinical Microbiology and Infection, 22, 110-121.

[60] Zaika, L.L. (2002) Effect of Organic Acids and Temperature on Survival of Shigella flexneri in Broth at pH 4. Journal of Food Protection, 65, 1417-1421. https://doi.org/10.4315/0362-028X-65.9.1417

[61] Abdalla, A.A., Suliman, S.E., Shuaib, Y.A. and Abdalla, M.A. (2014) Bacteriological Study of Poultry Meat in Semi-Automatic Abattoir in Khartoum State-Sudan. Sudan Journal of Science and Technology, 14, 80-85.

[62] Chuang, Y.C., Ko, W.C., Huang, G.C. and Hsu, S.Y. (1998) Infections Due to Non-O1 Vibrio cholerae in Southern Taiwan: Predominance in Cirrhotic Patients. Clinical Infectious Diseases, 27, 774-780. https://doi.org/10.1086/514947

[63] Ashiq, S. (2015) Natural Occurrence of Mycotoxin in Food and Feed: Pakistan Perspective. Comprehensive Reviews in Food Science and Food Safety, 14, 159-175. https://doi.org/10.1111/1541-4337.12122

[64] Ogu, G.I., Madar, I.H., Igborgbor, J., et al. (2017) Mycological Quality of Fresh and Frozen Chicken Meat Retailed within Warri Metropolis, Delta State, Nigeria. Jordan Journal of Biological Sciences, 10, 303-308.

[65] Omorodion, N.J.P.N. and Odu, N.N. (2014) Microbiological Quality of Meats Sold in Port Harcourt Metropolis, Nigeria. Natural Science, 12, 58-62. 
[66] Akond, M.A., Hassan, S.M., Alam, S. and Shirin, M. (2009) Antibiotic Resistance of Escherichia coli Isolated from Poultry and Poultry Environment of Bangladesh. American Journal of Environmental Sciences, 5, 47-52. https://doi.org/10.3844/ajessp.2009.47.52

[67] Al-Salauddin, A.S., et al. (2015) Isolation, Identification, and Antibiogram Studies of Salmonella Species and Escherichia coli from Boiler Meat in Some Selected Areas of Bangladesh. International Journal of Basic \& Clinical Pharmacology, 4, 999-1003. https://doi.org/10.18203/2319-2003.ijbcp20150881

[68] Gai, W., Wang, J., Wang, J., Cui, Z., Qu, Z., Cui, J., et al. (2015) Molecular Classification and Drug Resistance Analysis of Escherichia coli Isolated from Poultry in China. International Journal of Clinical and Experimental Medicine, 8, 836-844.

[69] Hasina, B. (2006) Enteropathotypic Characterization of Escherichia coli Isolated from Diarrhoeic Calves and Their Antibiogram Study. M.S. Thesis, Department of Microbiology and Hygiene, BAU, Mymensingh, 68.

[70] Hassan, J., Parvej, M.S., Rahman, M.B., Khan, M.S., Rahman, M.T., Kamal, T., et al. (2014) Prevalence and Characterization of Escherichia coli from Rectal Swab of Apparently Healthy Cattle in Mymensingh, Bangladesh. Microbes and Health, 3, 12-14. https://doi.org/10.3329/mh.v3i1.19775

[71] Huang, T.M., Lin, T.L. and Wu, C.C. (2009) Antimicrobial Susceptibility and Resistance of Chicken Escherichia coli, Salmonella spp. and Pasteurella multocida Isolates. Avian Diseases, 53, 89-93. https://doi.org/10.1637/8268-021608-Reg.1

[72] Mohammed, H.A. and Omer, A.F.A. (2015) Antibacterial Activity of Azadirachta indica (Neem) Leaf Extract against Bacterial Pathogens in Sudan. American Journal of Research Communication, 3, 246-251. http://www.usa-journals.com

[73] Maragathavalli, S., Brindha, S., Kaviyarasi, N.S., Annadurai, B. and Gangwar, S.K. (2012) Antimicrobial Activity in Leaf Extract of Neem (Azadirachta indica Linn.). International Journal of Security and Networks, 3, 110-113.

[74] Mamman, P.H., Mshelia, W.P., Susbatrus, S.C. and Sambo, K.W. (2013) Antibacterial Effects of Crude Extract of Azadirachta indica against Escherichia coli, Salmonella spp. and Staphylococcus aureus. International Journal of Medicine and Medical Sciences, 5, 14-18.

[75] Panchal, P., Bajaj, H. and Maheshwari, S. (2013) Azadirachta indica (NEEM): Antibacterial Effects against Escherichia coli and Salmonella guru Drone. Journal of Pharmacy and Research, 1, 18-21. 